\title{
ホウ素ドープ高純度炭化ケイ素セラミックスの焼結性と 特性に及ぼす酸化ベリリウム添加の影響
}

\author{
安富義幸・宮田素之・沢井裕一・近藤次郎* \\ (株) 日立製作所日立研究所，319-12 茨城県日立市大久加町 7-1-1 \\ *新日本製鐵(株) 先端技術研究所, 211 神奈川県川崎市中原区井田 1618
}

\author{
Effect of $\mathrm{BeO}$ on the Sintering and Properties of Boron-Doped High-Purity SiC Ceramics \\ Yoshiyuki YASUTOMI, Motoyuki MIYATA, Yuichi SAWAI and Jiro KONDO* \\ Hitachi Research Laboratory, Hitachi, Ltd., 7-1-1, Omika-cho, Hitachi-shi, Ibaraki 319-12 \\ *Advanced Materials \& Technology Research Laboratories, Nippon Steel, Corp., 1618, Ida, Nakahara-ku, Kawasaki-shi, Kanagawa 211
}

[Received October 12, 1994; Accepted January 19, 1995]

\begin{abstract}
In order to obtain pressureless-sintered $\mathrm{SiC}$ ceramics with high thermal conductivity, effect of $\mathrm{BeO}$ addition on sintering properties boron-doped $\beta$-SiC powder was investigated. The $\beta$-SiC powder was produced by the plasma arc method from $\mathrm{SiH}_{4}, \mathrm{~B}_{2} \mathrm{H}_{6}$ and $\mathrm{CH}_{4}$ gases. Pressureless-sintered boron-doped $\beta$-SiC ceramics showed high thermal conductivity of $180 \mathrm{~W} \cdot \mathrm{m}^{-1} \cdot \mathrm{K}^{-1}$ and electrical resistivity of $1100 \Omega \cdot \mathrm{m}(10 \mathrm{mV})$. On the other hand, pressureless-sintered boron-doped $\beta$-SiC ceramics containing $\mathrm{BeO}$ showed varistor characteristics with electrical resistivity of $10^{11} \Omega \cdot \mathrm{m}$ at $10 \mathrm{~V}$, and thermal conductivity of $230 \mathrm{~W} \cdot \mathrm{m}^{-1} \cdot \mathrm{K}^{-1}$. These ceramics consisted of net-like elongated $\beta$-SiC grains. Thus, addition of $\mathrm{BeO}$ increased the thermal conductivity and electrical resistivity.
\end{abstract}

Key-words : Silicon carbide, Beryllium oxide, Plessurelesssintering, Thermal conductivity, Electrical resistivity

\section{1. 緒 言}

熱衝撃を受ける高温部材では，耐熱性及び高熱伝導性を 有する材料が求められている. 高熱伝導材としては，窒化 アルミニウム $(\mathrm{AlN})$, 酸化ベリリウム $(\mathrm{BeO})$ ，炭化ケイ 素 (SiC) が知られているが， AlN は耐熱性， BeO は安全 性の点で適していない，炭化ケイ素（SiC）は共有結合性 の強い化合物であるために，耐熱性，熱伝導性に優れてい る反面, 難焼結性でもある. 無加圧焼結法よる $\mathrm{SiC}$ セラ ミックスの緻密な焼結体は，1973年に $\mathrm{SiC}$ 粉末の焼結助 剂としてホウ素 (B) と炭素 (C) が発見されて可能と なった1).また， $\mathrm{SiC} に$ 酸化べリリウム（BeO）を添加し， $2050^{\circ} \mathrm{C}, 30 \mathrm{MPa}, 1 \mathrm{~h}$ の条件でホットプレス焼結すること により，室温に打ける熱伝導率が $270 \mathrm{~W} \cdot \mathrm{m}^{-1} \cdot \mathrm{K}^{-1}$ と金属 アルミニウムより大きい材料が得られることが知られてい る2). しかし, $\mathrm{BeO}$ を焼結助剤とした $\mathrm{SiC}$ セミミッス は, ホットプレス法でしか高熱伝導性の焼結体を得ること ができず，今まで，無加圧焼結法により高熱伝導の焼結体 を得る方法は見いだされていなかった。

一方, $\mathrm{SiH}_{4}, \mathrm{~B}_{2} \mathrm{H}_{6}$ 及び $\mathrm{CH}_{4}$ ガスをプラズマ中で反応さ
せたホウ素を含有する超微粒 $\mathrm{SiC}$ 粉末を用いることによ り，無加圧で緻密な焼結体が得られる3)。この $\mathrm{SiC}$ 粉末 は，高純度のため高熱伝導 $\mathrm{SiC}$ 焼結体が得られる可能性 がある。

本研究では, 焼結性に優れたホウ素ドープ高純度 $\beta-\mathrm{SiC}$ 粉末を用い，これに $\mathrm{BeO}$ を添加，無加圧焼結法により $\mathrm{SiC}$ セラミックスを作製し，その焼結性及び焼結体の特性 評価を行い, 高純度 $\mathrm{SiC}$ 粉末の効果及び $\mathrm{BeO}$ 添加の効果 を確認することを目的とした。

\section{1 焼結体の作製方法}

\section{2. 実験方法}

本実験で使用したホウ素ドープ $\beta-\mathrm{SiC}$ 粉末は，直流プラ ズマ電源 $(15 \mathrm{~kW}) 3$ 本と高周波プラズマ電源 $(100 \mathrm{~kW})$ からなるハイブリッドプラズマ装置で製造した ${ }^{3)}$ 。この製 造法の優れている点は, $\mathrm{SiH}_{4}$ と $\mathrm{B}_{2} \mathrm{H}_{6}$ ガスにより極めて 混ざりやすい融体化ケイ素とホウ素だけを第 1 反応域に 生成させ，ホウ素を含む融体化ケイ素とした後に，第 2 反応域にて $\mathrm{CH}_{4}$ ガスにより炭化し， $\mathrm{SiC}$ とるため, $\mathrm{SiC}$ 粒子内にホウ素を含有する高純度の $\mathrm{SiC}$ 粉末が得られ ることにある ${ }^{3)}$. 得られた $\beta$-SiC 粉末の走査型電子顕微鏡 (SEM) 観察写真を図 1 (a), (b) に示す. 各 $\mathrm{SiC}$ 粉末の木 ウ素及び遊離炭素量を表 1 に示す. No. 1 , No. 2 の $\beta$-SiC 粉末は, 平均粒径はいずれも約 $0.3 \mu \mathrm{m}$ であり，外観上顕 著な差は認められない.No. 2 は，焼結性を高めることを 意識してNo. 1 に比較して遊離炭素量を若干多くしてい る.ここで, 遊離炭素量の測定は, 酸素気流中で加熱し遊 離炭素の分解量より求めた. $\mathrm{SiH}_{4}$ と $\mathrm{B}_{2} \mathrm{H}_{6}$ ガスの合成比 により決定されるホウ素の含有量は, プラズマ発光分光分 析法で求めた. 金属不純物は, 化学分析の結果, 各原料之 も30 ppm 以下と極めて微量である. また，プラズマ合成 した各 $\beta$ - SiC 粉末は, 空気中で取り扱うため, 0.35〜 0.39 mass\%の酸素を含有している.

原料粉末として各 $\beta$-SiC 粉末 (No. 1 , No. 2), 及び各 $\beta-\mathrm{SiC}$ 粉末 $40 \mathrm{~g}$ に対し, 焼結助剤として図 1(c)の SEM 写真 に示す平均粒径 $0.05 \mu \mathrm{m}$ の $\mathrm{BeO}$ 粉末（Brush \& Wellman 


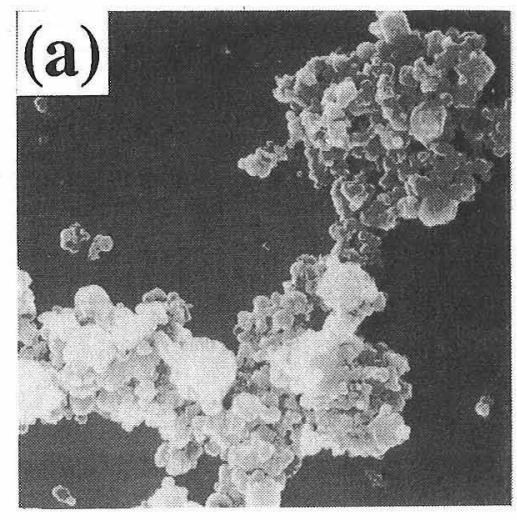

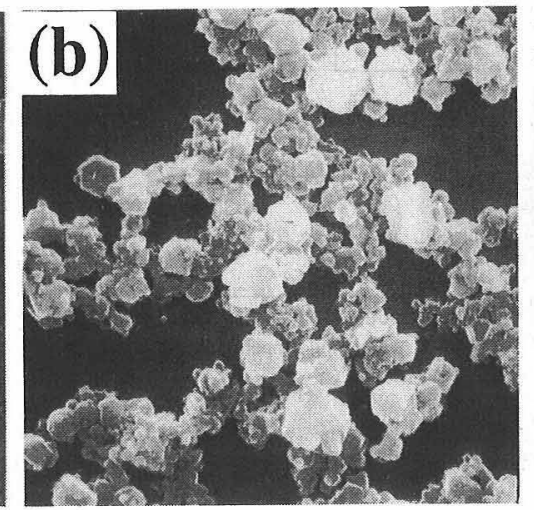

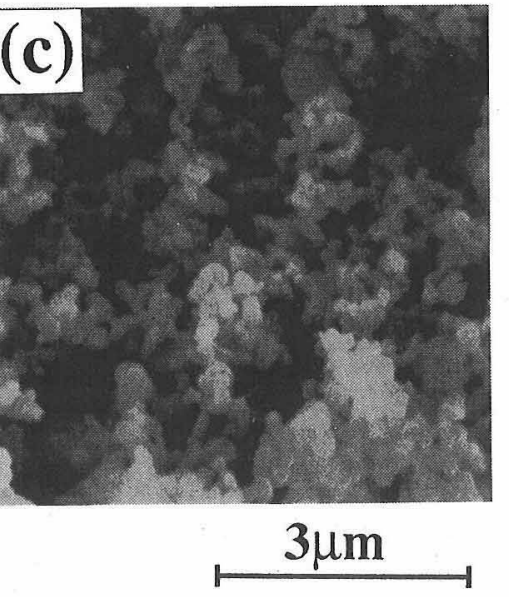

Fig. 1. SEM micrographs of (a) B-doped $\mathrm{SiC}:$ No. 1, (b) B-doped $\mathrm{SiC}:$ No. 2 and (c) BeO powders.

Table 1. Boron and Free-Carbon Contained in SiC Powders (mass\%)

\begin{tabular}{ccc}
\hline $\begin{array}{l}\text { Number of } \\
\text { SiC powder }\end{array}$ & Boron & Free-carbon \\
\hline No.1 & 0.27 & 1.45 \\
No.2 & 0.29 & 1.59 \\
\hline
\end{tabular}

No.3: 2 mass \% BeO added No.1

No.4: 2 mass $\%$ BeO added No.2

社製）を 2 mass\%添加したもの（No. 3, No. 4 ; 表 1 に示 す）を用いた。 これらに成形バインダーとして信越化学工 業製のシリコーン樹脂（KR272）をキシレンで $1: 1$ に希 釈した溶剤を 2 mass\%添加し，らいかい機で $1 \mathrm{~h}$ 混合し た。混合物を乾燥後， $43 \mu \mathrm{m}$ のふるいにより整粒し，成 形用原料とした，成形は，混合した各 $\mathrm{SiC}$ 粉末約 $2 \mathrm{~g}$ を内 径 $15 \mathrm{~mm}$ の金型に入れ，98 MPa の荷重で行った。圧粉 体は，直径 $15 \mathrm{~mm}$, 厚さ約 $6 \mathrm{~mm}$ で $\mathrm{SiC}$ の理論密度に対

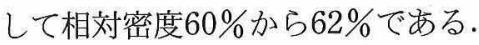

焼結については，各圧粉体を $\alpha-\mathrm{SiC}$ 粉末を敷いた内径 $200 \mathrm{~mm}$ の黒鉛容器中に置き, 誘導加熱型焼結炉を使用 し,アルゴンガス雾囲気中で処理した。 焼結は, 炉内を油 拡散ポンプを用いて5.1 mPa に減圧した後, アルゴンガス を導入して炉内压力を $0.03 \mathrm{MPa}$ に調整し, 目的の温度 $1900 \sim 2300^{\circ} \mathrm{C}$ まで $8^{\circ} \mathrm{C} \cdot \mathrm{min}^{-1}$ で昇温し所定時間保持後炉 冷した.

\section{2 比熱及び熱伝導率測定}

熱拡散率の測定は，レーザーフラッシュ法を用いて行っ た．装置は熱源としてルビーレーザーを用いた真空理工製 の TC-7000型を用いた. 温度検出は, InSb 赤外線検出セ ンサーを用いる非接触法である. 測定試料の寸法は直径 $10 \mathrm{~mm}$, 厚み $3 \mathrm{~mm}$ とし, 試料面には熱吸収が一定にな るように黒鉛をスプレー塗布（約 $0.01 \mathrm{~mm}$ 厚）して測定 した. なお，黒鉛のスプレ一塗布は，試料気孔中に黒鉛が 浸入しないように, 真空グリース（信越化学工業製, HIVAC-G；体積抵抗率 $9 \times 10^{14} \Omega \cdot \mathrm{m} ）$ を表面に薄く塗布 し紙ワイパーで拭き取り封孔後行った. 熱伝導率 $\lambda$ は次
式により求めた。

$$
\lambda\left(\mathrm{W} \cdot \mathrm{m}^{-1} \cdot \mathrm{K}^{-1}\right)=\eta \cdot \rho \cdot C_{P}
$$

ここで, $\eta$ : 熱拡散率 $\left(\mathrm{m}^{2} \cdot \mathrm{s}^{-1}\right), \rho$ : 密度 $\left(\mathrm{Mg} \cdot \mathrm{m}^{-3}\right), C_{P}$ : 比熱 $\left(\mathrm{J} \cdot \mathrm{kg}^{-1} \cdot \mathrm{K}^{-1}\right)$ である。

比熱については，示差走査熱量計（DSC 法）を用いて 測定した。測定条件は, 昇温速度 : $10^{\circ} \mathrm{C} \cdot \mathrm{min}^{-1}$, 感度 : $2.09 \mathrm{~mJ} \cdot \mathrm{s}^{-1}$, 雾囲気: 乾燥窒素気流, 測定温度 : $25^{\circ} \mathrm{C}$, 比熱校正：サファイヤである. 試料は半分に切断し, WC 乳鉢で $150 \mu \mathrm{m}$ 以下に粉砕した。比熱は, 各粉研試料より 2 回採取・測定し, 平均值を求めた。

\section{3 電気抵抗率の測定}

電気抵抗率は， $V-I$ 特性の測定より求めた。測定試料 の寸法は直径 $10 \mathrm{~mm}$, 厚み $3 \mathrm{~mm}$ とし, 試料両面に直径 $5 \mathrm{~mm}$ の金/パラジウムペーストを塗り電極とした．抵抗

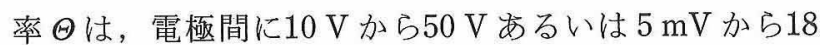
$\mathrm{mV}$ の電圧 $V$ を印加し，そのとき流れる電流 $I$ を測定し て, 次式より求めた。測定は, 各試料 2 回行い, 平均値 を求めた.

$$
\begin{aligned}
& R=V / I \\
& \Theta=R \cdot S / d
\end{aligned}
$$

ここで, $d:$ 試料厚さ $(\mathrm{m}), S:$ 電極の面積 $\left(\mathrm{m}^{2}\right), R$ : 電極 間の抵抗 $(\Omega)$ である.

\section{4 密度測定, $X$ 線回折及び組織観察}

焼結体のかさ密度は，水中置換法により求めた，焼結体 の X 線分析は, 理学電機製 RU-200型（広角）装置を用 い, $\mathrm{Cu}$ ターゲット，加速電压 $40 \mathrm{kV}$, 電流 $150 \mathrm{~mA}$ の条 件で行った。

焼結体については，アルカリ溶液によりエッチング処理 した研磨面，及び破面について観察を行った。観察は，光 学顕微鏡 (Olympus 製, BH2-UMA 型), 透過型電子顕 微鏡（TEM：日立製作所製，H-9000NAR）, SEM（日立 製作所製，S-570）を用いて行った.

\section{3. 結果及び考察}

\section{1 焼結性と焼結体の組織}

焼結温度を $1900^{\circ} \mathrm{C}$ から $2300^{\circ} \mathrm{C}$ をで変化させて得られた 


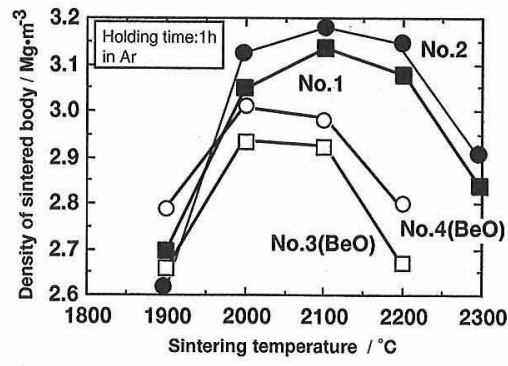

Fig. 2

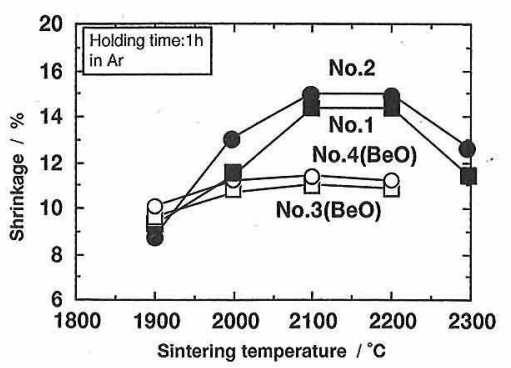

Fig. 3

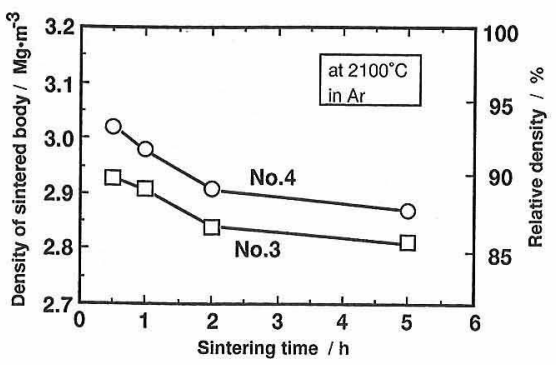

Fig. 4

Fig. 2. Relationship between density of sintered body and sintering temperature of B-doped $\mathrm{SiC}$ powders and B-doped $\mathrm{SiC}$ powders added BeO.

Fig. 3. Relationship between shrinkage and sintering temperature of B-doped $\mathrm{SiC}$ powders and B-doped $\mathrm{SiC}$ powders added BeO.

Fig. 4. Relationship between density of sintered body and sintering time of B-doped $\mathrm{SiC}$ powders added BeO.

各焼結体の密度を図 2, また, 焼結時の収縮率を図 3 に示 す．ホウ素ドープ $\mathrm{SiC}$ 焼結体は, 焼結温度 $2100^{\circ} \mathrm{C}$ で緻密 化（相対密度換算：99\%）しており，更に燒結温度が高 くなると密度が低下している. 図 3 の収縮率より, 最適 焼結温度が $2100{ }^{\circ} \mathrm{C}$ から $2200{ }^{\circ} \mathrm{C}$ であり, 焼結体密度の傾 向と一致する。それに対して, $\mathrm{BeO}$ 添加ホウ素ドープ $\mathrm{SiC}$ 焼結体は, 焼結温度 $1900{ }^{\circ} \mathrm{C}$ 加 $2000{ }^{\circ} \mathrm{C}$ と上昇すると ともに緻密化しているが，相対密度換算で最大 $94 \%$ $\left(2000{ }^{\circ} \mathrm{C}\right)$ にしか達して扔らず，更に焼結温度が高くなる と密度が低下している. 図 3 より, 收縮率は $2000{ }^{\circ} \mathrm{C}$ から $2200{ }^{\circ} \mathrm{C}$ に扔いて約 $11 \%$ で飽和しており，焼結性が低いこ とが分かる。ここで, 焼結温度 $2000^{\circ} \mathrm{C} て ゙$ 密度が最大の理 由は， $2100{ }^{\circ} \mathrm{C}$ 以上では後述するように $\mathrm{SiC}$ の分解などが 生じているためと考光られる. なた, 遊離炭素量の多い No. 4 の試料の方が No. 3 より緻密化しており, この傾向 はホウ素ドープ $\mathrm{SiC}$ 焼結体と同様である. 原料により密 度が異なる理由としては, $\mathrm{SiC}$ 焼結体の緻密化には炭素に よる表面酸化膜 $\mathrm{SiO}_{2}$ の除去及び $\mathrm{B}$ による拡散の促進によ る焼結が必要である4)ことから, 遊離炭素量及びホウ素量 の微妙な違いによる影響が考えられる。

ホウ素ドープ $\mathrm{SiC}$ 焼結体において, 最も緻密化した焼 結温度 $2100{ }^{\circ} \mathrm{C}$ において焼結時間を $0.5 \mathrm{~h}$ 加ら $5 \mathrm{~h}$ まで変化 して得られた $\mathrm{BeO}$ 添加ホウ素ドープ $\mathrm{SiC}$ 各焼結体の密度 及び相刘密度を図 4 に, 各試料の収縮率を図 5 に示す。

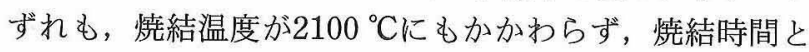
ともに密度は低下して抢り, 收縮率がほとんど変化してい

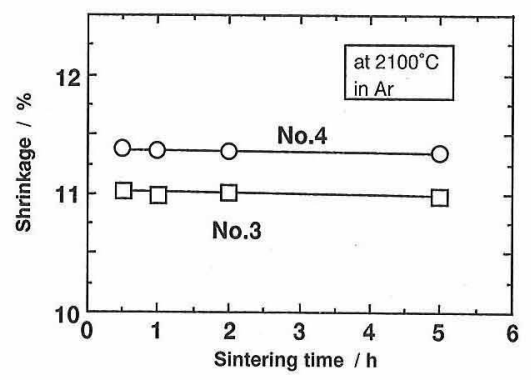

Fig. 5. Relationship between shrinkage and sintering time of B-doped $\mathrm{SiC}$ powders added $\mathrm{BeO}$.
ないことが分かる.これは， $2100^{\circ} \mathrm{C} に$ 抢いて $\mathrm{SiC}$ の分解 が生じていることを示唆している.

次に, 図 2 で得られた試料について, 組織が焼結温度 によりどう変化するかを調べるために，試料表面をエッチ ング処理した研磨面の試料中央部を光学顕微鏡で観察した 結果を図 6 に示す。また，X線回折による分析結果を 図 7, 図 8 に示す.なお，試料 No. 1 と No. 2 及びNo. 3 と No. 4 は，同様な組織及び組成のため，ここではNo. 2 とNo. 4 の試料について示す.

ホウ素ドープ $\mathrm{SiC}$ 焼結体では，図 6 より，2100 ${ }^{\circ} \mathrm{C}$ 処理 で100 $\mu \mathrm{m}$ 程度の針状結晶が多数生成し， $2200{ }^{\circ} \mathrm{C}$ 処理焼結 体では更に長い針状の $\mathrm{SiC}$ 粒子が生成している。この針

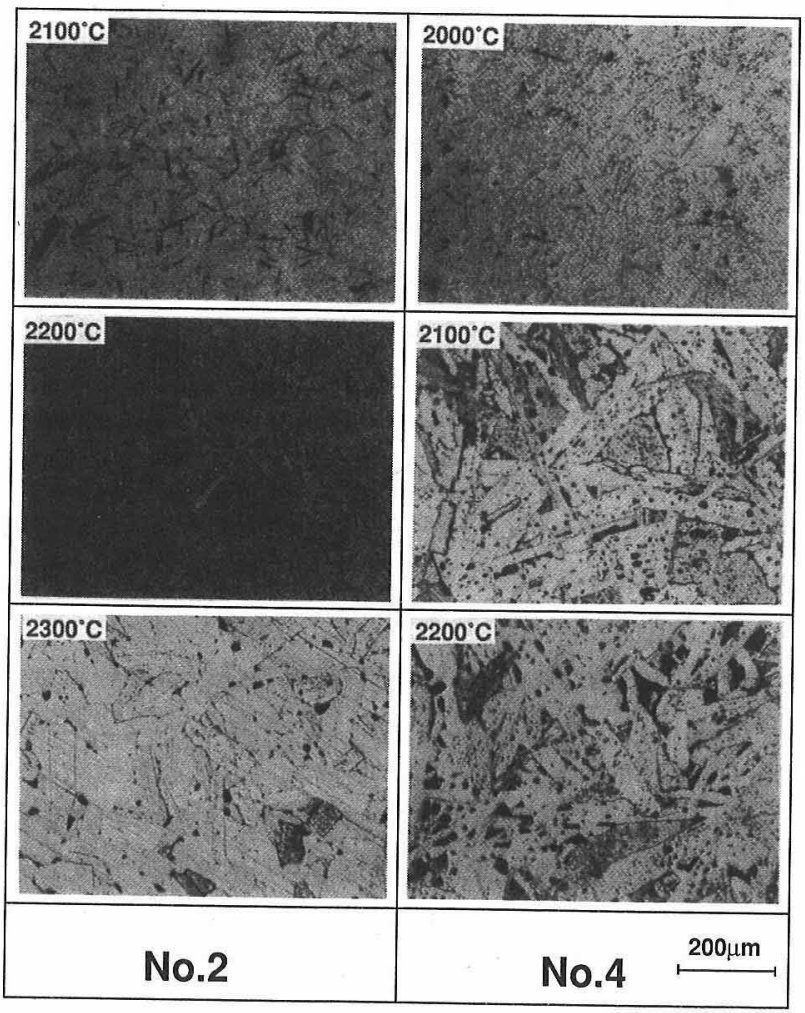

Fig. 6. Comparison of optical micrographs of etched surface of B-doped $\mathrm{SiC}$ ceramics (No. 2) and B-doped $\mathrm{SiC}$ added BeO ceramics (No. 4). 


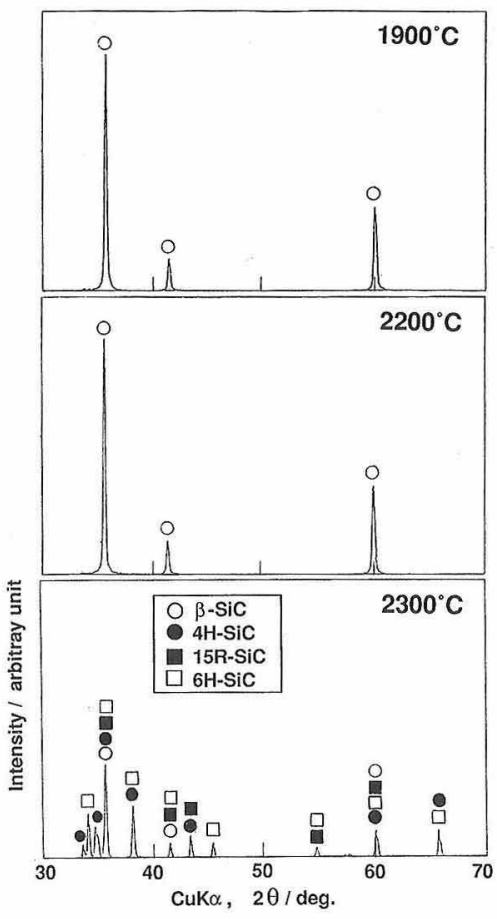

Fig. 7. X-ray diffraction patterns of B-doped $\mathrm{SiC}$ ceramics (No. 2) sintered at 1900,2200 and $2300^{\circ} \mathrm{C}$ for $1 \mathrm{~h}$.

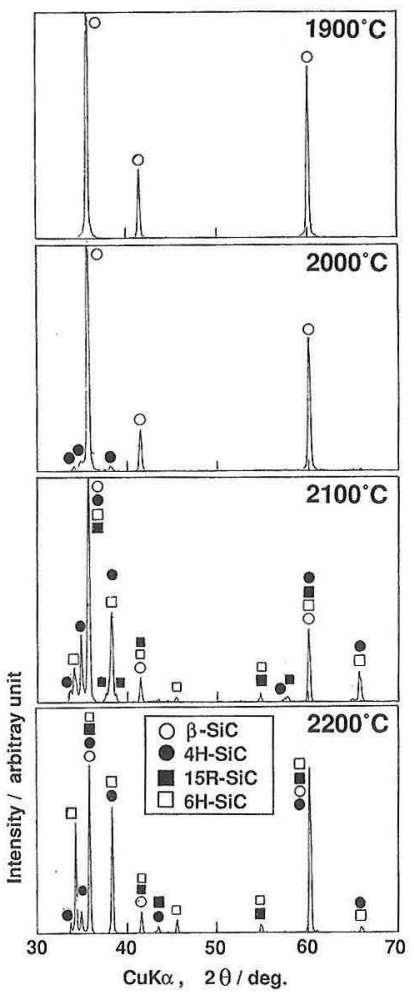

Fig. 8. X-ray diffraction patterns of B-doped $\mathrm{SiC}$ added $\mathrm{BeO}$ ceramics (No. 4) sintered at $1900,2000,2100$ and $2200^{\circ} \mathrm{C}$ for $1 \mathrm{~h}$.

状 $\mathrm{SiC}$ 粒子は, 図 7 の $\mathrm{X}$ 線回折線より $\beta-\mathrm{SiC}$ である. 図 9 に $2100^{\circ} \mathrm{C}$ 処理焼結体の TEM 像を示す。針状結晶が 絡み合った構造であることが分かる. $2300^{\circ} \mathrm{C}$ 処理では， 針状結晶は見られず，粒成長により粒子形状が大きくなっ ている。この粒成長は, 図 7 のX線回折より, $\beta$ - SiC

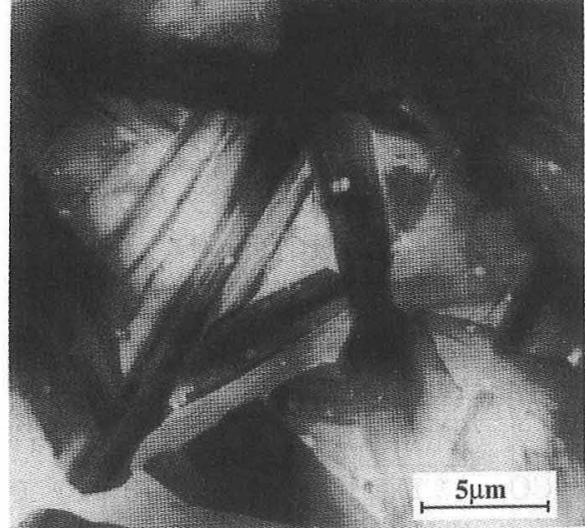

Fig. 9. TEM image of B-doped $\mathrm{SiC}$ ceramics sintered at $2100^{\circ} \mathrm{C}$ for 1 h.

(3C) から $\alpha-\mathrm{SiC}(4 \mathrm{H}, 15 \mathrm{R}, 6 \mathrm{H})$ への変化によるためであ ると考えられる，焼結温度 $2300^{\circ} \mathrm{C}$ に扔いて，粒界に気孔 が見られ（図6），密度が低下する（図2）原因としては 以下の二つが考えられる.一つは $\mathrm{SiC}$ の分解により気孔 が生成したこと，もう一つは繳密化した $2100^{\circ} \mathrm{C}$ 処理焼結 体に比較して収縮率が小さい（図 3）ことから，緻密化す る前に粒成長が生じ緻密化が抑制されたことが考えられ る.

$\mathrm{BeO}$ 添加ホウ素ドープ $\mathrm{SiC}$ 焼結体では, $2000^{\circ} \mathrm{C}$ 処理焼 結体は， $100 \mu \mathrm{m}$ 程度の針状結晶が分散しており（図 6), $\mathrm{BeO}$ 無添加焼結体の $2100^{\circ} \mathrm{C}$ 処理燒結体の組織とよく似て いるが，相対密度換算で最大 $94 \%$ にしか達していない。 また, $\mathrm{BeO}$ 無添加焼結体に比較して収縮率が小さく（図 3), 焼結性が低いことが分かる。この針状 $\mathrm{SiC}$ 粒子は, 図 8 の $\mathrm{X}$ 線回折線より $\beta$ - $\mathrm{SiC}$ である. $2100^{\circ} \mathrm{C}$ 処理焼結体 では, 粒子形状が大きな板状なっており, 粒間及び粒内に 気孔が見られ, $\mathrm{BeO}$ 無添加の $2300^{\circ} \mathrm{C}$ 処理焼結体の組織よ りも粒子形状が板状でかつ大きい。つまり, 粒成長がホウ 素ドープ $\mathrm{SiC}$ 焼結体よりも低温で起きていることが分か る. 更に $2200^{\circ} \mathrm{C}$ 処理焼結体では, 一層板状粒子形状が大 きくなっている，この粒成長は，図 8 のX線回折より, $\beta-\mathrm{SiC}(3 \mathrm{C})$ 加 $\alpha-\mathrm{SiC}(4 \mathrm{H}, 15 \mathrm{R}, 6 \mathrm{H})$ への変化によるた めであると考觉られる. また，このような板状の粒成長 は, 焼結助剂が少ない場合に界面エネルギーの綬和不足の ために生じると言われている5)。これは，図 3 より収縮が 阻害されていること, 及び後述する考察から, $\mathrm{BeO}$ 添加 により, 焼結助剂である炭素, ホウ素が消失あるいは化学 変化したことが原因と考えられる。また, 焼結温度 $2100^{\circ} \mathrm{C}$ 以上で粒間及び粒内に気孔が見られ（図 6), 密度 が低下する（図 2）原因としては， $\mathrm{SiC}$ の分解及び緻密化 する前に粒成長が生じたことによる焼結の抑制が考えられ るほかに, 後述するように, 焼結後ホウ素量が半減してい ることから， $\mathrm{BeO}$ 添加により $\mathrm{B}_{2} \mathrm{O}_{3}$ が生成し, 生成した $\mathrm{B}_{2} \mathrm{O}_{3}$ が約 $2030^{\circ} \mathrm{C}$ で蒸発が生じる6)ためと推測される.

図 4 で得られた焼結体に扔いても，2100 $\mathrm{C}$ で焼結時間 が長くなるに伴い板状の粒成長が促進され, 粒間・粒内で 
の気孔の存在が確認されていることから，同様の原因で密 度が低下していると考えられる。

以上の結果において， $\mathrm{BeO}$ を添加することにより，焼 結性が低下して緻密化しない原因について考察する.

一つには， $\mathrm{SiC}$ 表面の酸化膜の除去及びホウ素酸化物の 還元効果をもたらす遊離炭素が $\mathrm{BeO}$ と(1) 式の反応を生 じ，酸化膜の還元効果がなくなったことが考えられる.

$$
\mathrm{C}+\mathrm{BeO} \rightarrow \mathrm{CO} \uparrow+\mathrm{Be}
$$

$\mathrm{JANAF}$ の熱化学表6)より, $\mathrm{CO}$ 及び $\mathrm{BeO}$ の標準生成ギブ スエネルギー $\left(\mathrm{J} \cdot \mathrm{mol}^{-1}\right)$ は, $2027^{\circ} \mathrm{C}, 0.1 \mathrm{MPa}$ の条件に おいて, $\mathrm{CO}:-3.11 \times 10^{5}, \mathrm{BeO}:-3.73 \times 10^{5}$ である。 $\mathrm{CO}_{2}$ の生成は, 焼結雾囲気がアルゴンガス中グラファイ ト加熱であるため無視できる.アルゴンガス中の不純物酸 素は数十 ppm であるため, $2027^{\circ} \mathrm{C}, 0.1 \mathrm{MPa}$ の条件に抢 いて CO の分圧は $1.01 \mathrm{~Pa}$ 程度となる. (1) 式の両辺のギ ブスエネルギーの大小関係を比較すると,

$$
0+\left(-3.73 \times 10^{5}\right)>\left(-3.11 \times 10^{5}\right)+R T \ln (1.01)+0
$$

となり，この反応は十分起こり得る．ここで， $R$ はガス定 数， $T$ は絶対温度である.

ここで，焼結体中の遊離炭素量を分析した結果，No. 3 では1.45 mass\%から 0.13 mass\%, No. 4 では 1.59 mass\% から0.20 mass\%と激減していることが分かった。これは， 遊離炭素と $\mathrm{SiC}$ 表面の酸化膜 $\mathrm{SiO}_{2}$ との反応だけでなく,

(1) 式の遊離炭素と $\mathrm{BeO}$ との反応が生じたことが推測さ れる.

二つには，ホウ素が酸化物と反応しやすいことから7)， $\mathrm{SiC}$ 表面の酸化膜との反応山るいは $\mathrm{BeO}$ との反応により $\mathrm{B}_{2} \mathrm{O}_{3}$ を生成し，焼結助剤の役割を果たすことができな かったことが考えられる.

$$
\begin{aligned}
& 2 \mathrm{~B}+3 \mathrm{SiO}_{2} \rightarrow \mathrm{B}_{2} \mathrm{O}_{3}+3 \mathrm{SiO} \uparrow \\
& 2 \mathrm{~B}+3 \mathrm{BeO} \rightarrow \mathrm{B}_{2} \mathrm{O}_{3}+3 \mathrm{Be}
\end{aligned}
$$

(3)式は熱力学的に $2700^{\circ} \mathrm{C}$ 以上の高温でないと起こりえ ない.しかし，(2)式の反応によりホウ素が $\mathrm{B}_{2} \mathrm{O}_{3}$ に変化 することは考えられる．そこで，焼結体中の小ウ素量を分 析した結果，No. 3 では0.27 mass\% か 50.15 mass\%, No. 4 では0.29 mass\%から 0.16 mass\%， と約半減してい ることが確認された.これは, ホウ素が(2)式により $\mathrm{B}_{2} \mathrm{O}_{3}$ に変化し, $\mathrm{B}_{2} \mathrm{O}_{3}$ の沸点が約 $2030^{\circ} \mathrm{C}$ である6) ことから， $\mathrm{B}_{2} \mathrm{O}_{3}$ が消失したものと考えられる.

また，二次イオン質量分析法（SIMS）により，焼結助 剂として添加した $\mathrm{BeO}$ が焼結体中にどのような形態で分 散しているか分析を行った結果, $\mathrm{SiC}$ 粒界に $\mathrm{BeO}$ として 分散していることを確認している8). $\mathrm{BeO}$ の存在について 考察すると，原料の $\mathrm{BeO}$ がそのまま残存する以外に， (1) 式で Be が生成すると同時に次式に示す反応により $\mathrm{BeO}$ が生成したことが熱力学的に十分考えられる.

$$
\mathrm{Be}+\mathrm{SiO}_{2} \rightarrow \mathrm{BeO}+\mathrm{SiO} \uparrow
$$

以上のような反応により, 焼結助剤である炭素, ホウ素 が消失あるいは化学変化したために, 焼結が抑制されたこ とが推測される。
ここで, $\beta-\mathrm{SiC}$ 粉末に $\mathrm{BeO}$ を添加し $2200^{\circ} \mathrm{C}$ で焼結した 場合， $\beta$ から $\alpha$ への相变化を生じるが $4 \mathrm{H}$ 構造で安定とな り, $6 \mathrm{H}$ 構造に変化しないことが報告されている ${ }^{9)}$. 本研 究では, $\mathrm{BeO}$ を添加して焼結した結果, 焼結温度の上昇 に伴い $6 \mathrm{H}$ 構造が生成することが確認された．これは， $\beta$ $\mathrm{SiC}$ 粉末自身にホウ素及び遊離炭素が含まれているために 多形変化を生じたものと考えられる5).

以上より, 焼結性に優れるホウ素ドープ $\mathrm{SiC}$ 粉末に $\mathrm{BeO}$ を添加することは，焼結性を低下させる原因となる ことが分かった。

\section{2 熱伝導率}

以下の測定は, 緻密化したホウ素ドープ $\mathrm{SiC}$ 焼結体 No. 2, BeO 添加ホウ素ドープ $\mathrm{SiC}$ 焼結体 No. 4 の試料に ついてのみ行った. 図10に比熱の測定結果を示す. 比熱 は, いずれも $660 \mathrm{~J} \cdot \mathrm{kg}^{-1} \cdot \mathrm{K}^{-1}$ 前後と一定であり, $\mathrm{BeO}$ 添 加による影響は見られなかった。

図11及び図12に室温 $\left(20^{\circ} \mathrm{C}\right)$ に打ける熱拡散率の測定 結果を示す. 図中の各点は, 試料 1 個について行った 2 回の平均值を示す. 測定のばらつきは， $5 \%$ 以内であった.

$\mathrm{BeO}$ 添加した焼結体の熱拡散率は, $\mathrm{BeO}$ 無添加の焼結体 より大きい.ここで, $\mathrm{BeO}$ 添加ホウ素ドープ $\mathrm{SiC}$ 焼結体 の熱拡散率の值の焼結温度, 焼結時間による変化は, 密度 の傾向と一致していることが分かる.しかし，ホウ素ドー プ $\mathrm{SiC}$ 焼結体の熱拡散率は, 最も緻密な $2100^{\circ} \mathrm{C}$ 処理焼結 体よりも， $2200^{\circ} \mathrm{C}$ 処理焼結体の方が大きい。この理由と しては， $2200^{\circ} \mathrm{C}$ 処理品焼結体 $2100^{\circ} \mathrm{C}$ よりも粒子が針状に 伸び，粒界が減少したことが考えられる。

図13に密度, 比熱, 熱拡散率から求めた熱伝導率を示

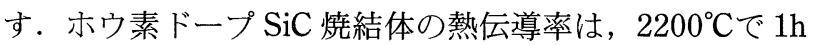
処理することにより， $180 \mathrm{~W} \cdot \mathrm{m}^{-1} \cdot \mathrm{K}^{-1}$ が得られた。
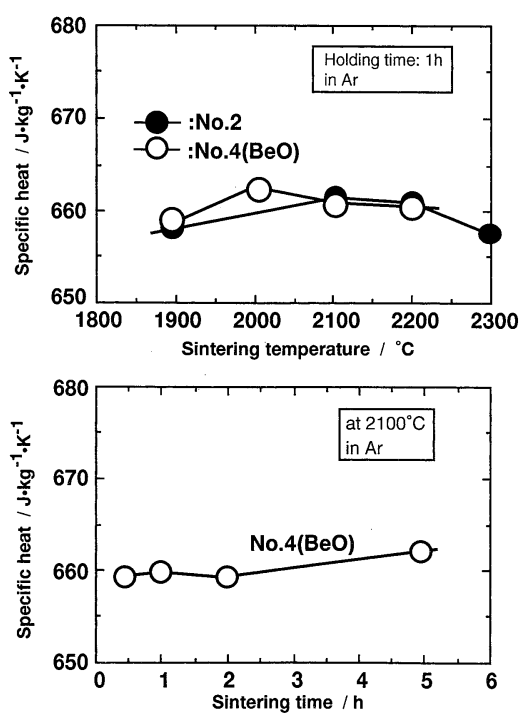

Fig. 10. Relationship between specific heat and sintering temperature or sintering time of B-doped $\mathrm{SiC}$ powder and B-doped $\mathrm{SiC}$ powder added $\mathrm{BeO}$. 


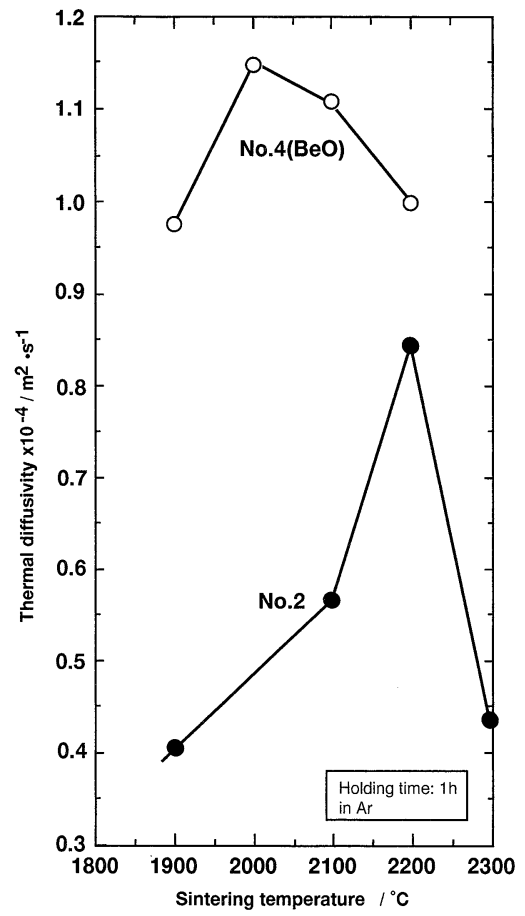

Fig. 11. Relationship between thermal diffusivity and sintering temperature of B-doped $\mathrm{SiC}$ powder and B-doped $\mathrm{SiC}$ powder added $\mathrm{BeO}$.

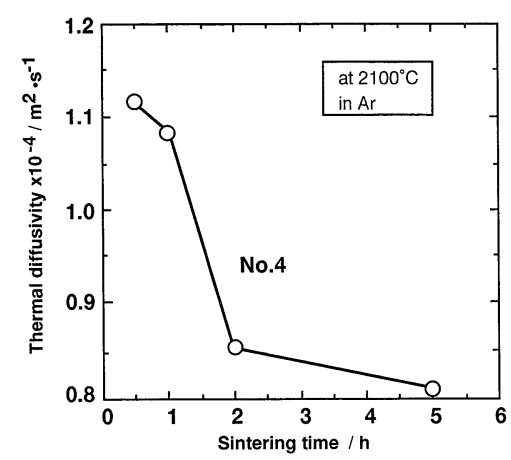

Fig. 12. Relationship between thermal diffusivity and sintering time of B-doped $\mathrm{SiC}$ powder added $\mathrm{BeO}$.

$\mathrm{BeO}$ 添加ホウ素ドープ $\mathrm{SiC}$ 焼結体の熱卮導率は, 密度が 小さいにもかかわらずホウ素ドープ $\mathrm{SiC}$ 焼結体よりも高 い値を示している. $2000^{\circ} \mathrm{C} て ゙ 1 \mathrm{~h}$ 処理することにより，最 大熱伝導率 $230 \mathrm{~W} \cdot \mathrm{m}^{-1} \cdot \mathrm{K}^{-1}$ が得られた．ここで, Maxwell-Euken の熱伝導に対する気孔率の補正式10)により， 緻密体の熱伝導率を逆算してみる.

$$
\lambda=\lambda_{0} \cdot(1-P) /(1+0.5 P)
$$

ここで, $P$ : 気孔率, $\lambda_{0}:$ 気孔率 0 の熱伝導率である.こ れより，

$$
\begin{aligned}
\lambda_{0} & =\lambda \cdot(1+0.5 P) /(1-P) \\
& =230 \times(1+0.5 \times 0.07) /(1-0.07) \\
& =256 \mathrm{~W} \cdot \mathrm{m}^{-1} \cdot \mathrm{K}^{-1}
\end{aligned}
$$

が求をる．この補正式は厳密ではないが，もし緻密化でき
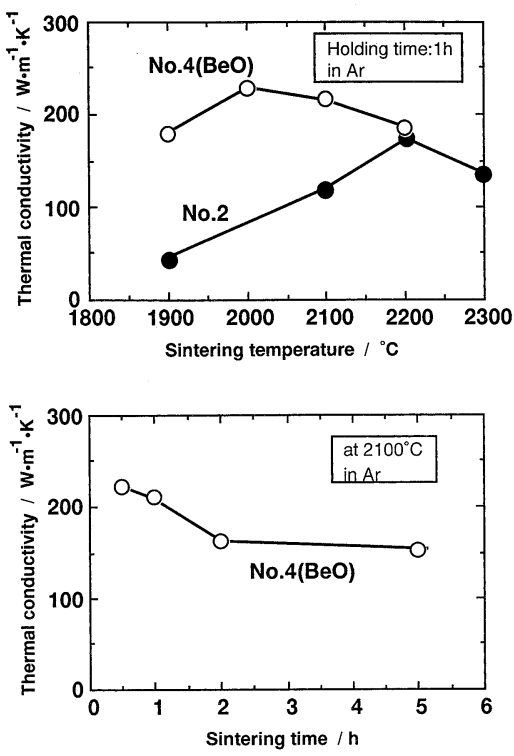

Fig. 13. Relationship between thermal conductivity and sintering temperature or sintering time of $\mathrm{B}$-doped $\mathrm{SiC}$ powder and $\mathrm{B}$ doped $\mathrm{SiC}$ powder added $\mathrm{BeO}$.

れば $\mathrm{BeO}$ 添加 $\mathrm{HP}-\mathrm{SiC}$ の熱伝導率（約 $270 \mathrm{~W} \cdot \mathrm{m}^{-1} \cdot \mathrm{K}^{-1}$ ) とほぼ同等になることが予想される。

$\mathrm{BeO}$ を添加することにより，94\%の相対密度にもかか わらず熱伝導率が比較的大きい理由は，3.1節の反応式で 示したようにフォノンの散乱因子となる遊離炭素, ホウ素 が除去されたことが考えられる。

以上, 本研究で得られた無加圧焼結ホウ素ドープ $\mathrm{SiC}$ セラミックスの熱伝導率は, $\mathrm{BeO}$ 添加ホットプレス $\mathrm{SiC}$ $\left.\left(270 \mathrm{~W} \cdot \mathrm{m}^{-1} \cdot \mathrm{K}^{-1}\right)^{2}\right)$ に比較して若干小さいが， $\mathrm{B}_{4} \mathrm{C}$ 添加 無加圧焼結 $\left.\mathrm{SiC}\left(125 \mathrm{~W} \cdot \mathrm{m}^{-1} \cdot \mathrm{K}^{-1}\right){ }^{11}\right)$ や $\mathrm{Al}_{2} \mathrm{O}_{3}$ 添加無加圧 焼結 $\mathrm{SiC}\left(45 \mathrm{~W} \cdot \mathrm{m}^{-1} \cdot \mathrm{K}^{-1}\right)^{12)}$ よりも 2 倍以上大きい。 そ して，ホウ素ドープ $\mathrm{SiC}$ 粉末に $\mathrm{BeO}$ を添加することによ り, 熱伝導特性を約1.3倍向上できることが確認された.

\section{3 電気抵抗率}

$\mathrm{BeO}$ 添加ホットプレス $\mathrm{SiC}$ 焼結体では, 絶縁体が得ら れることが知られている2),13)。そこで，本研究の無加圧焼 結 $\mathrm{BeO}$ 添加ホウ素ドープ $\mathrm{SiC}$ 焼結体についても同様に, 絶縁性を有するか確認を行った．図14にホウ素ドープ $\mathrm{SiC}$ 焼結体及び $\mathrm{BeO}$ 添加ホウ素ドープ $\mathrm{SiC}$ 焼結体の室温 における電気抵抗率測定結果を示す。これより, $\mathrm{BeO}$ 無 添加では約 $1100 \Omega \cdot \mathrm{m}$ の半導体の領域にある. そして, $\mathrm{BeO}$ を添加することにより, $10^{11} \Omega \cdot \mathrm{m} \sim 10^{9} \Omega \cdot \mathrm{m}$ の高絶 縁性を有し, 電圧の増加に伴い抵抗が減少するバリスター 特性を有することが確認された。この特性は, $\mathrm{BeO}$ 添加 ホットプレス $\mathrm{SiC}$ 焼結体とほぼ一致する.

以上より, ホウ素ドープ $\mathrm{SiC}$ 粉末に $\mathrm{BeO}$ を 2 mass\%添 加し, 無加圧焼結法により焼結体を作製した結果, $10^{11}$ $\Omega \cdot \mathrm{m} \sim 10^{9} \Omega \cdot \mathrm{m}$ の高絶縁性 $\mathrm{SiC}$ 焼結体が得られることが 分かった。 

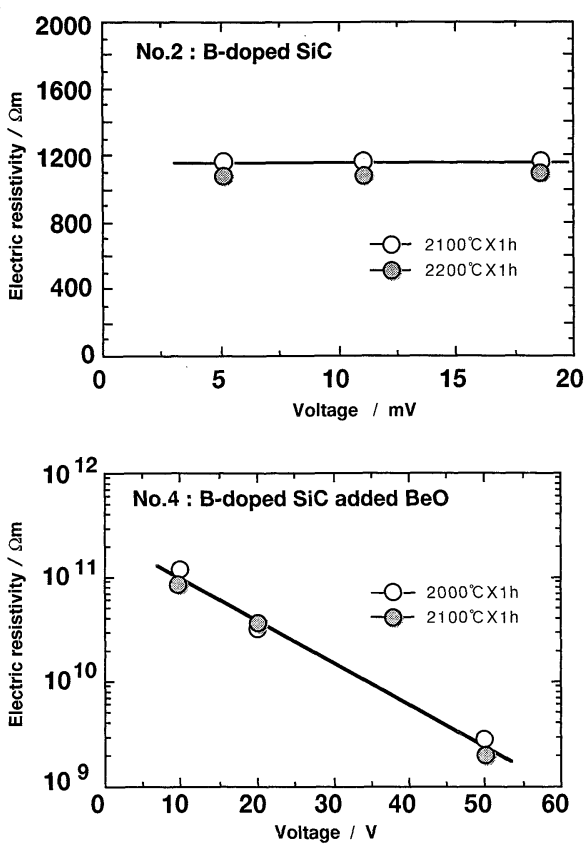

Fig. 14. Comparison of electric resistivity of B-doped $\mathrm{SiC}$ sintered body and B-doped $\mathrm{SiC}$ sintered body added $\mathrm{BeO}$.

\section{4. 結 言}

ホウ素ドープ高純度 $\beta$ - $\mathrm{SiC}$ 粉末に $\mathrm{BeO}$ を 2 mass\%添加 し，無加圧焼結法により焼結体を作製し，その焼結性及び 焼結体の特性に対する $\mathrm{BeO}$ 添加の影響について検討し， 以下の結論が得られた。

(1) ホウ素ドープ $\mathrm{SiC}$ 粉末を, $\mathrm{Ar}$ 䨌囲気中, $2200^{\circ} \mathrm{C}$ で $1 \mathrm{~h}$ 処理することにより，最大熱伝導率 $180 \mathrm{~W} \cdot \mathrm{m}^{-1}$. $\mathrm{K}^{-1}$, 電気抵抗率 $1100 \Omega \cdot \mathrm{m}(10 \mathrm{mV})$ の特性を有する 3 次元針状構造の無加圧焼結 $\beta$-SiC セラミックスが得られ る.

(2) $\mathrm{BeO}$ 添加ホウ素ドープ $\mathrm{SiC}$ 粉末を, $\mathrm{Ar}$ 雲囲気中, $2000^{\circ} \mathrm{C}$ で $1 \mathrm{~h}$ 焼結することにより，最大熱伝導率 $230 \mathrm{~W} \cdot$ $\mathrm{m}^{-1} \cdot \mathrm{K}^{-1}$ ，電気抵抗率 $10^{11} \Omega \cdot \mathrm{m}(10 \mathrm{~V})$ の特性を有する 相対密度 $94 \%$ の $\beta$-SiC 焼結体が得られる.

（3） $\mathrm{BeO}$ を添加することにより，熱伝導率を約 1.3 倍 向上できる.

（4） ホウ素ドープ $\mathrm{SiC}$ 焼結体の比熱は， $\mathrm{BeO}$ の添加に よる影響がなく，約 $660 \mathrm{~J} \cdot \mathrm{kg}^{-1} \cdot \mathrm{K}^{-1}$ である.

（5） $\mathrm{BeO}$ 添加ホウ素ドープ $\mathrm{SiC}$ 焼結体は， $10^{11} \Omega \cdot \mathrm{m} \sim$ $10^{9} \Omega \cdot \mathrm{m}$ の高絶縁性を有し, 電圧の増加に伴い抵抗が減 少するバリスター特性を有する.

（6） $\mathrm{BeO}$ を添加することにより， $\mathrm{SiC}$ の焼結性が低下 し，緻密化が阻害される。

\section{文献}

1) S. Prochazka and R. J. Charls, Am. Ceram. Soc. Bull., 52, 12, 885-91 (1973).

2）例えば, Y. Takeda, K. Nakamura, K. Maeda and M. Ura, Advanced Ceram. Mater., 1, 162-65 (1986).

3) J. Kondo and G. Saiki, "Ceramic Transactions, Vol. 1", Part A, Am. Ceram. Soc. (1988) pp. 285-92.

4）長谷貞三，鈴木弘茂，寗協，88，258-64 (1980).

5）田中英彦，猪股吉三，佃 一志，萩村 厚，寗協， 92, 461-65 (1984).

6) D. R. Stull and H. Prophet, "JANAF Thermochemical Tables", 2nd ed., The Thermal Research Laboratory, Dow Chemical Company (1968).

7）イ・エス・クリコフ，“酸化物の熱力学”，日ソ通信社 (1969) pp. 139-42.

8）田中 滋, 安富義幸, 沢井裕一, 宮田素之, 坂口 勲, 高 橋 研, J. Ceram. Soc.Japan，投稿中。

9）添田厚子, 前田邦裕, 鈴木康隆, 㸃協, 94, 651-60 (1986).

10）丸山忠司，“ファインセラミックス評価技術集成”，リアラ イズ社 (1984) pp. 100-05.

11）工業材料 3 月別冊, ファインセラミックスデータブック, 日刊工業新聞社 (1993) p. 179 .

12）小野拓郎, “旭硝子(株)の $\mathrm{SiC}$ セラミックス：炭化ケイ素と 窒化ケイ素及びセラミックス繊維強化”，ティー・アイ・ シー (1992) pp. 141-46.

13) K. Maeda, Y. Takeda, A. Soeta, K. Usami and S. Shinozaki, “Ceramic Microstructures '86", Ed. by J. A. Pask and A. G. Evans, Plenum Press (1988) pp. 757-65. 